\title{
INOVASI DALAM KOMPETISI: USAHA KULINER LOKAL MENCIPTAKAN KEUNGGULAN KOMPETITIF DI UBUD
}

\author{
Putu Diah Sastri Pitanatri \\ Program Studi Magister Kajian Pariwisata Universitas Udayana \\ Sekolah Tinggi Pariwisata (STP) Nusa Dua, Bali \\ Email: diahsastri@gmail.com
}

\begin{abstract}
Esteemed for its culture, Ubud has developed its image as culinary destination in Bali. The creation of this new branding of Ubud is attached to the dedication of its local talents who consistently serves Balinese food to tourists. Seeing these ongoing developments, this study analyzes the following aspects (1) Ubud and it's development as culinary destination, (2) innovation showed by local culinary talents, and (3) thin line between cultural enrichment and deprivation. Using critical qualitative, this research was conducted by implementing indepth interviews to selected interviewes.Theories used are cultural tourism and sustainable tourism approaching to related aspects such as experience economy, millennial generation; community based tourism, and invented tradition. Results of this study are (1) the development of Ubud as culinary destination in Bali is not only supported by changes in tourist's motivation but also the ability of it's local talents to productively innovate (2) innovation in products, promotions and experiences are the keys in promoting sustainability of these local businesses, and (3) the growth of local culinary enrich cultural experience and is proven to strengthening Ubud's image as a cultural tourism destination.
\end{abstract}

Keywords : Balinese food, culinary destinations, innovation, sustainable tourism, image

\section{Pendahuluan}

Perkembangan Ubud sebagai destinasi pariwisata dunia berimplikasi terhadap tingginya minat investor untuk membuka bisnis di daerah ini. Investasi tidak hanya terjadi pada bisnis hotel dan villa, namun juga pada restoran dan rumah makan. Hal ini juga disebabkan banyaknya ekspatriat dan masyarakat luar pulau yang tinggal selama bertahun-tahun di Ubud dan "rindu" akan masakan kampung halaman atau negeri asalnya. Hal ini kemudian semakin memperketat persaingan antara pengusaha-pengusaha 
kuliner, baik lokal maupun nonlokal. Situs TripAdvisor tahun 2016 mencatat terdapat 516 restoran yang terdapat di kawasan Ubud. Jumlah ini belum termasuk rumah makan kecil dan menengah yang tidak tercatat dalam situs tersebut.

Di tengah ketatnya persaingan dan semakin menjamurnya restoran nonlokal, masakan lokal dengan ciri khas Bali sangat mudah untuk ditemui di Ubud. Masakan khas Bali di Ubud terbukti memberikan pengalaman budaya yang otentik bagi wisatawan domestik maupun mancanegara. Masakan tidak hanya berfungsi sebagai pemuas rasa lapar namun berkembang dan menjadi salah satu pendukung penting daya tarik pariwisata di destinasi ini.

Pentingnya kuliner dan wisata kuliner bagi wisatawan didukung oleh banyak peneliti (Telfer dan Wall, 2000; Hjalager dan Richards 2002; Hall dan Sharples 2003; Kivela dan Crotts, 2006; Okumus et al, 2007; Sims 2009). Minat ini didorong oleh peningkatan jumlah destinasi yang memanfaatkan sumber daya kuliner mereka di dalam mempromosikan dan membedakan destinasinya dengan destinasi pesaing, misalnya, Australia, Selandia Baru, Italia, dan Singapura (Chang et al, 2010; Hall dan Mitchell, 2002; Scarpato 2002).

Kuliner lokal adalah komponen fundamental dari atribut sebuah destinasi, menambah berbagai atraksi dan keseluruhan pengalaman wisata (Symons, 1999). Yurseven dan Kaya (2011) juga menyebutkan bahwa kuliner lokal merupakan cara terbaik untuk melihat warisan budaya tak benda sebuah destinasi adalah melalui konsumsi. Selain itu, wisata kuliner mendukung produsen, dan masyarakat lokal untuk memberikan hasil budi daya lokal untuk menghasilkan makanan berkualitas untuk wisatawan (Long, 2004). Ini menunjukkan bahwa pengembangan wisata kuliner di sebuah destinasi wisata dapat menghasilkan manfaat bagi masyarakat lokal dan wisatawan yang berkunjung ke destinasi tersebut (Nummedal dan Hall, 2006; Okumus et al, 2007; Sims, 2009).

Penciptaan branding melalui kuliner lokal di Ubud tidak terlepas dari peran para tokoh kuliner yang secara konsisten mempertahankan cita rasa "kebalian"-nya melalui beragam inovasi yang dilakukan sampai saat ini. Secara spesifik, artikel ini menelusuri inovasi para tokoh kuliner lokal di Ubud dalam memperkenalkan dan mengangkat makanan khas Bali kepada masyarakat luas, khususnya wisatawan domestik dan mancanegara.

Sayang sekali sampai saat ini studi mengenai kuliner sebagai atribut baru di dalam pengembangan pariwisata budaya di sebuah destinasi masih sangat minim. Selain Putra (2014), belum ada penelitian yang mengkaji mengenai tokoh-tokoh kuliner di Ubud termasuk penelitian mengenai faktor pendukung kuliner lokal di Ubud. Untuk mengisi kekurangan dalam literatur pariwisata serta untuk memberikan bukti-bukti yang lebih komprehensif, artikel ini mengungkapkan bagaimana tokoh kuliner di 
Ubud mampu mempertahankan eksistensi bahkan mengembangan usaha di tengah derasnya arus kompetisi restoran dan warung makan di Ubud.

Penelitian kualitatif ini merujuk kepada empat pengusaha kuliner Bali di Ubud yang dipilih yaitu Sang Ayu Mangku pemilik dari Nasi Ayam Kedewatan Ibu Mangku, Anak Agung Oka Raka Sinar pemilik Babi Guling Bu Oka, Anak Agung Raka Sueni pemilik rumah makan Bebek Bengil dan Ni Luh Made Puspawati pemilik Paon Bali cooking class. Kriteria pemilihan mereka ada lima yaitu: (1) Merupakan penggagas dan pemilik usaha kuliner Bali di Ubud; (2) Merupakan usaha yang pertama kalinya mempopulerkan ragam kuliner tersebut di Ubud, untuk wisatawan domestik dan mancanegara; (3) Tingginya tingkat publikasi media nasional dan internasional, online maupun offline; (4) Jumlah dan kualitas penghargaan yang diterima baik dalam tingkat nasional dan internasional dan (5) Memiliki rating yang baik di TripAdvisor, sekurang-kurangnya pernah mendapatkan penghargaan TripAdvisor Traveller's Choice Awards .

Keempat tokoh tersebut diwawancarai melalui metode in depth interview untuk mendapatkan gambaran dan deskripsi yang jelas mengenai kreativitas mereka dalam melakukan inovasi-inovasi kuliner Bali. Untuk memperdalam pembahasan, artikel ini ditulis dengan menggabungkan informasi dari artikel di media massa, observasi langsung sebagai konsumen, serta sumber online yang memuat informasi tokoh dan usaha mereka tersebut.

\section{Kuliner Bali di Ubud}

Asosiasi antara kuliner Bali dan Ubud saat ini pun terasa begitu canggung. Sampai beberapa tahun yang lalu, Ubud hampir tidak pernah diapresiasi atas kekayaan kuliner Bali-nya. Kritikan justru menunjuk Ubud sebagai destinasi yang sudah terlalu komersil, tenggelam dalam dominasi restoran dan warung non-lokal. Kontradiktif dengan hal tersebut, penelitian ini justru menemukan empowerment dari masyarakat lokal melalui kuliner Bali. Bukannya tersisih, pengusaha lokal yang secara serius mengembangkan kuliner Bali terbukti mendapatkan manfaat terbesar dari usaha kuliner lokal.

Perkembangan kuliner Bali di Ubud sebenarnya telah dimulai dengan dibukanya beberapa restoran lokal yang tidak hanya menjadi konsumsi masyarakat namun juga wisatawan baik domestik maupun mancanegara. Babi Guling Bu Oka (1990), Nasi Ayam Kedewatan Ibu Mangku (1990), Bebek Bengil (1996) dan Paon Bali Cooking class adalah empat pionir yang memperkuat eksistensi Ubud sebagai destinasi kuliner Bali.

Popularitas keempat usaha kuliner ini sejalan dengan perkembangan pasar Ubud yang saat ini didominasi oleh wisatawan yang dikenal dengan sebutan generation $Y$ atau Millenia. Generasi millenias, generasi Y atau echo boomers merupakan generasi yang lahir dari tahun 1977-1994 (Kapoor dan Solomon, 2011). Mereka merupakan pasar yang atraktif untuk dua hal. 
Pertama, preferensi dan selera yang dibentuk selama waktu remaja dapat mempengaruhi pembelian sepanjang waktu. Kedua, saat ini remaja mampu menghabiskan lebih dari \$150 juta per tahun untuk konsumsi personalnya (Hawkins dan Mothersbaugh, 2010). Kebanyakan dari uang yang mereka peroleh juga akan dibelanjakan pada "feel-good" products atau produkproduk yang mampu memberikan kenyamanan bagi mereka, seperti kosmetik, poster, dan makanan (Solomon, 2009).

Dominasi millenias di Ubud terlihat pada situs video online YouTube. Sampai saat ini tercatat 36.700 video yang diunggah ke YouTube dengan filter "Ubud Food" sementara kata kunci "Ubud Culinary" memiliki 7.940 video. Besarnya pengaruh media ini terlihat pada salah satu video yang dalam kurun waktu hanya 5 bulan (Januari 2016) sudah mendapatkan 29.464 views. Di situs pencari Google, keyword "Ubud Food" bahkan mendapatkan 7.670.000 results (jauh diatas keyword "Balinese food" yang hanya mendapat 277.000 results (Juni 2016). Hal ini menunjukkan besarnya peran media online di dalam penciptaan image Ubud sebagai destinasi kuliner Bali.

Nasi ayam kedewatan Ibu Mangku misalnya, populer setelah banyak wisatawan yang menuliskan review di TripAdvisor dan blog pribadi mereka. Pada awalnya warung ini merupakan persinggahan supir-supir suplier yang membawakan hasil bumi ke Denpasar. Guide rafting yang bekerja di Sungai Ayung (1990-an) juga mulai tertarik makan di warung Ibu Mangku dan memperkenalkan warung tersebut secara luas. Kemudian setelah beberapa resor di daerah Sayan dibuka, mulailah warung kecil ini ramai oleh wisatawan yang mendapat rekomendasi dari guide-nya. Nasi Ayam Kedewatan juga sangat populer di kalangan wisatawan domestik yang mengunjungi Ubud namun mencari makanan yang "halal".

Berbeda halnya dengan Babi Guling Bu Oka, warung makan yang sebelumnya hanya popular di kalangan para masyarakat lokal ini menjadi lebih populer setelah ditayangkan pada salah satu acara milik stasiun TV TMC No Reservation pada tahun 2006. Seperti yang disebutkan Putra (2014:83) popularitas babi guling Bu Oka sempat menjadi magnet yang dapat menarik selebriti TV dunia Anthony Bourdain, untuk datang ke Ubud membuat feature story tentang masakan Indonesia dan Bali dan menjadikan suckling pig Bu Oka sebagai satu fokus perhatian.

Perkembangan kuliner Ubud juga tampak pada beberapa buku yang ditulis oleh penulis asing dan lokal. Ubud yang dulunya hanya ada di bukubuku museum, seni dan pagelaran, kini masakan lokal Ubud sudah mulai muncul dalam cookbook seperti Bali Unveiled: The Secrets of Balinese Cuisine (2004) karya Chef Heinz von Holzen dan Bali: Food of My Island (2011) karya Janet de Neefe,. Buku resep masakan Bali karya Janet juga pernah dinominasikan sebagai Best Asian Cuisine Book versi Gourmand World CookBook Awards. 
Ubud yang kaya akan budaya, saat ini eksisitensi semakin diperkuat dengan adanya kuliner Bali yang memberi manfaat ekonomi, sosial budaya serta lingkungan yang berkelanjutan bagi masyarakatnya. Melalui kreativitas mayarakatnya dalam mengembangkan kuliner Bali, tidak ada destinasi wisata di Bali yang citra kulinernya sekaya Ubud, sama kuatnya dengan citra budayanya.

\section{Inovasi Pengusaha Kuliner Bali di Ubud}

Meningkatnya popularitas Ubud dengan atribut baru sebagai destinasi wisata kuliner didukung oleh kreativitas pengusaha kuliner Bali di Ubud berinovasi dalam tiga hal yaitu (1) produk, (2) promosi dan (3) penciptaan pengalaman bagi wisatawan. Ketiga inovasi ini dibahas lebih lanjut berikut ini.

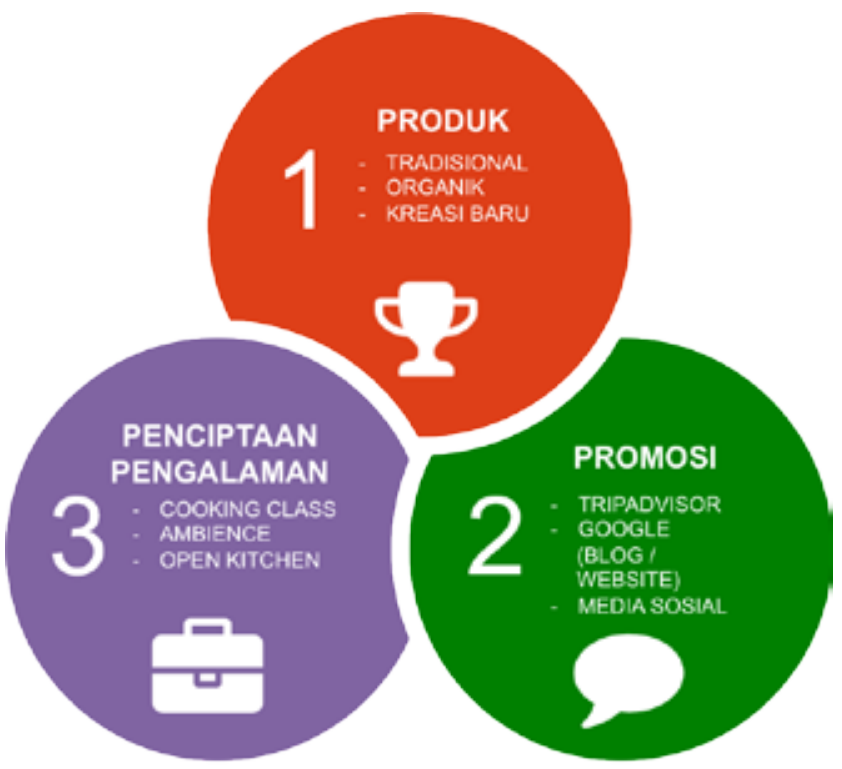

Gambar 1 Inovasi Pengusaha Kuliner Lokal dalam Mempertahankan Eksistensi dan Mengembangkan Usahanya. Sumber: Hasil Penelitian, 2016

\subsection{Inovasi Produk}

Kedinamisan masyarakat Ubud tidak hanya tercermin dari seni dan budaya namun juga dari kuliner Balinya. Dengan tidak menghilangkan cita rasa lokal, adaptasi dilakukan sehingga makanan ini dapat diterima oleh wisatawan. Adapun ragam kuliner Bali yang menjadi kekuatan destinasi ini diantaranya:

\section{a. Tradisional}

Babi Guling Bu Oka dan Nasi ayam Kedewatan Ibu Mangku merupakan 
dua contoh di mana masakan lokal tradisional langsung menjadi konsumsi wisatawan. Dari segi rasa, kedua masakan ini memang tidak sepedas masakan Bali pada umumnya. Sambal pada masakan di kedua warung ini sengaja dipisah sehingga dapat menyesuaikan selera masing-masing konsumen.

\section{b. Organik}

Tren hidup sehat dan berkembangnya wisatawan yang sadar akan pentingnya hidup sehat membuat makanan organik semakin digemari. Perkembangan Ubud sebagai destinasi wellness dan retreat juga semakin mempolulerkan warung lokal yang menggunakan konsep ini. Warung Bodag Maliah dan Padi Organik adalah dua diantara banyak warung yang menawarkan konsep makanan sehat namun tetap memiliki cita rasa Bali

\section{c. Kreasi Baru Berbasiskan Tradisional.}

Bebek Bengil merupakan salah satu warung tradisional yang mengkreasikan ulang kuliner tradisional dengan konsep Bali. Bebek bengil misalnya mengganti bebeknya menjadi bebek semi organik yang diberi pakan khusus sehingga dagingnya tidak berbau amis. Bebek-bekek ini tetap dibumbui dengan bumbu Bali namun pengolahan serta pengemasan dilakukan secara modern sehingga tercipta standarisasi rasa. Teknik memasaknya pun dikreasikan sehingga diperoleh bebek yang crispy; sedikit berbeda dengan pengolahan bebek Bali pada umumnya.
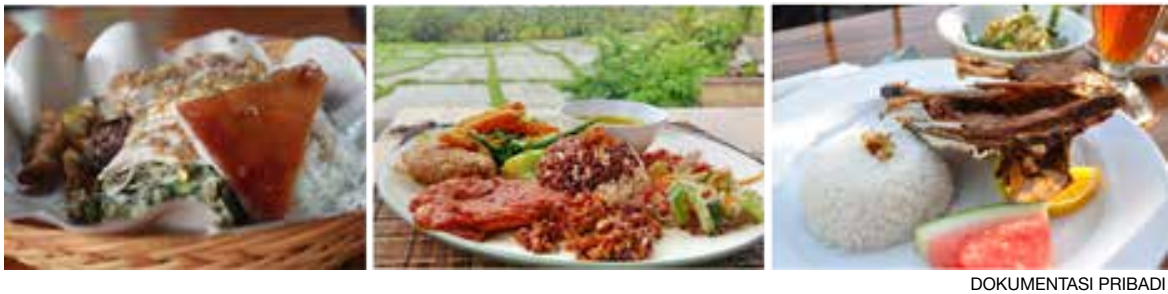

Foto 1. Dari Kiri ke Kanan: Tradisional (Nasi Ayam Kedewatan Bu Mangku), Organik (Bodag Maliah) dan Kreasi Baru (Bebek Bengil).

\subsection{Inovasi Promosi}

Tidak seperti restoran besar yang memiliki budget besar untuk promosi, warung lokal harus kreatif mempromosikan warung makannya. Baik Bu Oka (Babi Guling Bu Oka), Ibu Mangku (Nasi Ayam Kedewatan Ibu Mangku) maupun Ibu Puspa (Paon Bali Cooking Class), tidak pernah melakukan promosi secara khusus. Yang mereka lakukan hanya upaya menciptakan kualitas makanan yang baik sehingga orang mau datang lagi dan mengajak teman atau saudaranya untuk datang kembali.

Konsep dasar promosi ini disebut sebagai word of mouth. Referensi dan endorsement melalui teman dan keluarga inilah yang merupakan 
"nafas" eksistensi usaha warung makan lokal. Perkembangan teknologi dan informasi akhirnya memunculkan situs-situs online yang memperkuat eksistensi warung lokal di Ubud. Terhadap penciptaan word of mouth, para pengusaha lokal kini dibantu oleh para netizen yang turut mempopulerkan ragam kuliner Bali di Ubud.

Secara garis besar terdapat 3 jenis promosi tidak berbayar yang dilakukan oleh para netizen baik domestik maupun mancanegara yaitu melalui TripAdvisor, Google (melalui blog dan website personal), dan media sosial. Ketiga aktivitas promosi tersebut dijabarkan dalam tabel berikut ini.

Tabel 1. Inovasi Promosi yang Memperkuat Branding Kuliner Lokal di Ubud.

\begin{tabular}{|c|c|c|c|c|}
\hline & $\begin{array}{l}\text { Nasi Ayam Kede- } \\
\text { watan Ibu Mangku }\end{array}$ & $\begin{array}{c}\text { Babi Guling Bu } \\
\text { Oka }\end{array}$ & Bebek Bengil & $\begin{array}{c}\text { Paon Bali Cooking } \\
\text { Class }\end{array}$ \\
\hline TripAdvisor & $\begin{array}{l}4.0 \text { of } 5 \text { stars } \\
152 \text { Reviews } \\
\text { Certificate of Ex- } \\
\text { cellence } 2007\end{array}$ & $\begin{array}{l}3.5 \text { of } 5 \text { stars } \\
1.806 \text { Reviews } \\
\text { Certificate of Ex- } \\
\text { cellence } 2009\end{array}$ & $\begin{array}{l}3.5 \text { of } 5 \text { stars } 1.656 \\
\text { Reviews } \\
\text { Certificate of } \mathrm{Ex}- \\
\text { cellence } 2010\end{array}$ & $\begin{array}{l}\text { 5.o of } 5 \text { stars } \\
2.316 \text { Reviews } \\
\text { Certificate of Ex- } \\
\text { cellence } 2015\end{array}$ \\
\hline $\begin{array}{l}\text { Popularitas di } \\
\text { Google (berdasar- } \\
\text { kan keywords) }\end{array}$ & $\begin{array}{l}24.000 \text { results } \mathrm{di} \\
\text { google }\end{array}$ & $\begin{array}{l}\text { 82.900 results di } \\
\text { google }\end{array}$ & $\begin{array}{l}\text { 21.ooo results di } \\
\text { google }\end{array}$ & $\begin{array}{l}39.900 \text { results } \mathrm{di} \\
\text { google }\end{array}$ \\
\hline Media Sosial & $\begin{array}{l}\text { - Facebook page } \\
\text { (219 like, } 5 \cdot 710 \\
\text { check in) } \\
\text { - } 348 \text { video di } \\
\text { YouTube } \\
\text { - } 475 \text { post di } \\
\text { instagram }\end{array}$ & $\begin{array}{l}\text { - Facebook page } \\
\text { (7.816 like, } \\
18.743 \text { check } \\
\text { in) } \\
\text { - } 3.270 \text { video di } \\
\text { YouTube } \\
\text { - } 263 \text { post di } \\
\text { instagram }\end{array}$ & $\begin{array}{l}\text { - Facebook page } \\
(1.152 \text { like, } \\
12.620 \text { check in) } \\
\text { - } 6.180 \text { video di } \\
\text { YouTube } \\
\text { - } 9.498 \text { post di } \\
\text { instagram }\end{array}$ & $\begin{array}{l}\text { - Facebook page } \\
(282 \text { like, } 1.322 \\
\text { check in) } \\
\text { - } 349 \text { video di } \\
\text { YouTube }\end{array}$ \\
\hline
\end{tabular}

Sumber: Penulis, Juni 2016

Tabel 1 menunjukkan bahwa Facebook dan Google memegang peranan yang sangat besar di dalam penciptaan branding dari usaha kuliner lokal di Ubud. Dari tabel tersebut juga tampak Babi Guling Bu Oka merupakan kuliner lokal yang paling populer di dunia maya jika dibandingkan dengan tiga usaha kuliner lokal lainnya. Hal ini menunjukkan bahwa citra Ubud sangat identik dengan Babi Guling ala bu Oka.

Popularitas yang hampir sepenuhnya didukung oleh para netizen ini turut memberi amdil terhadap eksposur media elektronik yang semakin mempopulerkan usaha kuliner Bali tersebut. Tidak tanggung-tanggung, media nasional maupun media internasional sampai membuat liputan khusus seperti tampak pada foto berikut ini

Yang menarik, selain Bebek Bengil, ketiga aktivitas promosi dalam tabel diatas dilakukan sepenuhnya oleh para netizen secara gratis. Inovasi promosi ini kemudian dilanjutkan oleh generasi penerus mereka yang mulai paham terhadap pentingnya dukungan teknologi di dalam mempertahankan eksisitensi sebuah usaha. Suatu saat nanti manajemen online media akan 

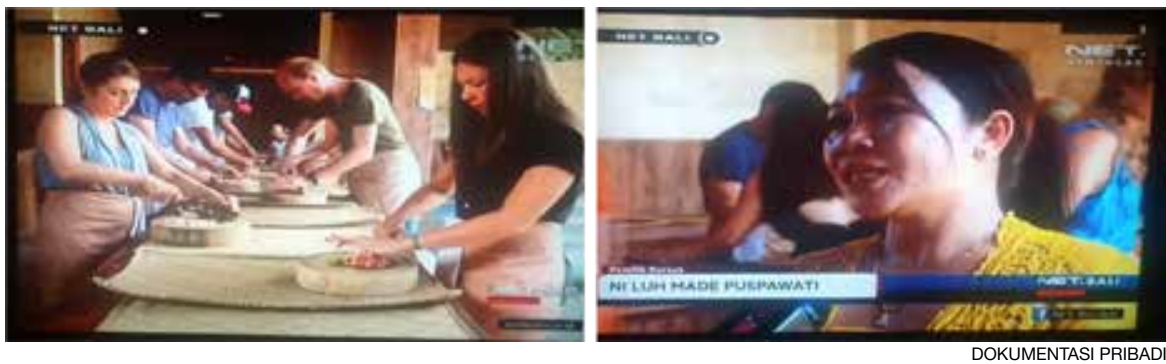

Foto 2

Promosi Tidak berbayar Paon Bali Cooking Class di Net TV tayang 16 Juni 2016

menjadi prioritas bagi setiap usaha yang bergerak di bidang kepariwisataan. Oleh sebab itu aktivitas promosi ini harus dilakukan secara professional sehingga efek positif melalui eksposur dunia digital tetap dapat dirasakan hingga puluhan tahun mendatang.

\subsection{Inovasi Penciptaan Pengalaman Wisatawan}

Dalam wawancara yang dilakukan terhadap keempat usaha kuliner lokal di Ubud, elemen experience merupakan inovasi yang sagat berpengaruh terhadap eksistensi usaha kuliner Bali d Ubud. Penciptaan pengalaman memberikan kesempatan bagi wisatawan untuk merasa nyaman, bahkan terlibat langsung dalam proses memasak. Terdapat tiga bentuk penciptaan pengalaman yang dilakukan yaitu melalui cooking class, penciptaan ambience serta konsep open kitchen.

Cooking class dulunya tidak pernah dianggap sebagai bagian dari pariwisata Ubud, namun dengan berkembangnya tipologi wisatawan peminat kuliner, maka cooking class kemudian menjadi salah satu top this to do in Ubud versi TripAdvisor. Konsep Paon Bali Cooking Class, misalnya, sebelum memasak wisatawan diajak ke pasar tradisional dan persawahan. Selama perjalanan, wisatawan mendapatkan pengalaman untuk mengikuti langsung pola hidup masyarakat Bali di pedesaan sambil mendengarkan konsep-konsep Bali seperti subak, bale (rumah tradisional) Bali, pasar tradisional dan sebagainya.

Konsep tersebut mengadopsi konsep pola hidup orang Bali zaman dulu. Setiap bangun pagi, mencari kayu api, kelapa dan ketela. Jika mendapat sedikit, maka semuanya dibawa ke pasar. Namun jika mendapat cukup banyak, maka setengah akan dibawa ke pasar, setengahnya lagi disimpan untuk dikonsumsi sendiri. Setelah dari pasar, biasanya istirahat dulu di bale dangin (bangunan yang terletak di sebelah timur), minum kopi, setelah itu baru melanjutkan bekerja kembali. Hal ini menciptakan elemen pengalaman (experience) yang sangat berkesan bagi wisatawan.

Inovasi yang tidak kalah pentingnya adalah menciptakan ambience atau suasana tradisional Bali yang membuat wisatawan "betah" berlama-lama 
di warung makan tersebut. Bebek Bengil, misalnya, yang memiliki cabang di luar Bali, konsep tradisional selalu mejadi aspek penting dalam penaan interior warung makan tersebut. Ciri khas Bali seperti tudung tumpang tiga (payung tingkat tiga khas Bali) selalu menghiasi setiap pintu masuk warung makannya.

Inovasi terakhir adalah konsep open kitchen yang merupakan inovasi penting untuk menjaga kepercayaan wisatawan terhadap kualitas dan higinitas pengolahan bahan. Dapur tradisional yang dulunya terkesan jorok karena tidak menggunakan prinsip sanitasi yang baik, saat ini berubah menjadi dapur terbuka dimana wisatawan dan pelanggan dapat melihat secara langsung proses memasak kuliner tersebut.

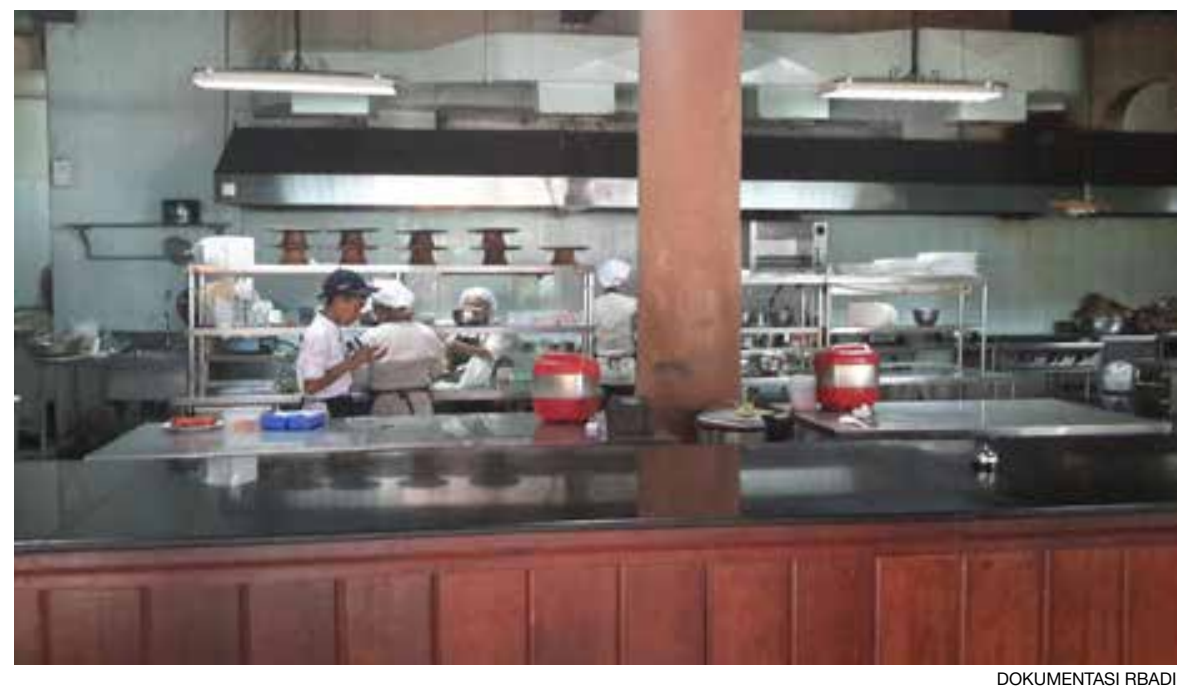

Foto 3.Konsep Open Kitchen di Restoran Bebek Bengil

Kreatifitas melalui inovasi yang dilakukan para pengusaha kuliner lokal Bali di Ubud memberi harapan eksistensi dan popularitas masakan Bali akan tetap terjaga. Produk, promosi serta penciptaan pengalaman wisatawan yang positif akan beimplikasi terhadap keberlanjutan usaha kuliner lokal ditengah ketatnya persaingan usaha kuliner di Ubud.

\section{Inovasi dalam Kompetisi: Kreasi atau Kremasi?}

Terhadap pesatnya persaingan yang mengharuskan para pengusaha kuliner lokal untuk melakukan inovasi seringkali dianggap sebagai bentuk komodifikasi budaya. Masakan Bali yang dibuat tidak sepedas masakan aslinya disebut sebagai bentuk turistifikasi yang dikhawatirkan memberi perubahan besar bagi budaya masyarakat lokal.

Sejumlah studi menunjukkan bahwa kuliner dalam pariwisata tunduk pada pengaruh makro globalisasi (Hall dan Mitchell, 2002a; Richards, 
2002; Symons, 1993; Torres, 2002). Seperti misalnya, ada kekhawatiran bahwa imperialisme budaya (Tomlinson, 1991) dan McDonaldisation (Ritzer, 1995) dapat menyebabkan homogenisasi yang dapat menghasilkan "global palate" serta masakan global (Richards, 2002; Ritzer, 1995; Symons, 1993). Oleh karena itu, globalisasi melalui pariwisata secara signifikan dapat mempengaruhi identitas gastronomi lokal dan image dari lanskap gastronomi sebuah destinasi (Fox, 2007; Harrington, 2005), dan dapat mengakibatkan perampasan dari "taste of place" bagi penduduk setempat dan wisatawan (Richards, 2002). Hasil seperti itu akan mengancam tujuan yang memanfaatkan kuliner lokal dan produk gastronomi sebagai sumber daya tarik wisata atau sebagai pembeda utama.

Terlepas dari pendapat tersebut, Ubud memberikan fenomena lain. Image Ubud sebagai destinasi wisata kuliner lokal merupakan atribut baru yang menjadikan budaya kuliner Ubud semakin kuat akibat pariwisata. Dengan adanya pariwisata, budaya kuliner dapat "dijual” sehingga tidak hanya memberikan manfaat ekonomis namun juga terbukti memberi manfaat sosial-budaya serta pelestarian lingkungan

Budaya yang bersifat dinamis, mengikuti pola perkembangan masyarakatnya. Bentuk-bentuk budaya yang berasal masyarakat biasanya terbentuk melalui koneksi yang dirasakan dengan masa lalu yang 'diciptakan,' 'dibayangkan,' 'direkonstruksi,' atau 'dibuat' (Briggs, 1996: 435). Hobsbawm (1983) juga menyebutkan bahwa tradisi sebenarnya diciptakan, dibangun dan resmi diikuti oleh mayasarakat yang berada didalamnya secara turun-temurun. Penciptaan tradisi ini tidak lain merupakan bentuk dari adaptasi manusia terhadap lingkungannya yang berubah.

Sebagai ilustrasi bisa disebutkan tradisi kuliner Belanda yang dikenal dengan nama"rijstaffel". Rijstaffel merupakan tradisi yang diadopsi dan diadaptasi dari negeri jajahannya, Indonesia. Seperti halnya spaghetti yang dibawa oleh Marcopolo ke Italia sebagai adopsi dari kuliner mie yang ditemuinya saat berlabuh di Cina. Budaya kuliner seperti ini merupakan budaya yang merupakan adaptasi dari budaya lain yang kemudian disesuikan dengan ketersediaan sumber daya setempat.

Contoh keterkaitan yang erat antara makanan dan unsur geografis misalnya tercermin dari penyajian Babi Guling Ibu Oka dengan ingka (piring tradisional yang terbuat dari bambu). Hal ini menyiratkan bahwa secara fisik, daerah ini kaya akan pohon bambu, sehingga dapat memproduksi piring dari anyaman bambu. Alasan yang sama terlihat dari suguhan ayam bumbu ala Manado yang dikukus menggunakan bambu panjang. Hal ini dapat menginformasikan adanya limpahan pohon bambu di tanah Minahasa.

Kuliner Bali termasuk yang hadir tercipta sebagai ikon destinasi wisata Ubud seperti babi guling dan nasi ayam Kedewatan saat ini pun juga mengalami proses modifikasi dan adaptasi sebagai bentuk dari standarisasi. 
Secara tradisional, takaran rempah-rempah yang digunakan untuk membuat bumbu Bali menggunakan ukuran jari. Jari tengah adalah takaran untuk isen (lengkuas), telunjuk untuk kunyit (kunir), jari manis untuk jahe, dan kelingking untuk cekuh (kencur).

Adaptasi dilakukan untuk memperoleh standarisasi rasa dan kualitas. Hal ini dilakukan karena jika hanya satu orang saja yang memiliki "tangan yang baik" untuk memasak, maka pengembangan usaha tidak akan dapat dilakukan. Harus ada takaran dalam ukuran yang pasti (kilogram) sehingga rasa masakan relatif sama dari tahun ke tahun. Nasi Ayam Kedewatan misalnya melakukan standarisasi takaran sehingga memiliki rasa yang sama meskipun kuliner tersebut dinikmati pada salah satu cabangnya yang tidak berada di Ubud. Selain adaptasi dari sisi takaran, tingkat kepedasan juga dikurangi melalui sambal yang disajikan dipisah. Meskipun demikian cita rasa yang dihasilkan tidak mengurangi cita rasa asli Bali. Hal tersebut mirip seperti yang dilakukan oleh Mie Kober di daerah Renon, Denpasar dan Kripik Maicih di Bandung yang menawarkan "level" kepedasan yang disesuikan dengan selera konsumen.

Tidak kalah pentingnya adalah standar higienitas dan sanitasi. Makanan Bali terkenal mudah basi sehingga harus dinikmati saat itu juga. Oleh sebab itu, Bu Oka dan Ibu Mangku melakukan usaha preventif dengan meningkatkan standarisasi higinitas untuk membuat wisatawan merasa yakin "tidak akan sakit perut" saat makan di warungnya. Standarisasi ini misalnya menggunakan sarung tangan saat mengolah makanan, dapur yang bersih dan sebagainya.

Tanpa disadari para pengusaha lokal ini telah menciptakan tradisi baru kuliner Bali yang dikelola secara moderen. Konsep dan cita rasa Bali tetap ada meskipun di adaptasikan dan disesuaikan dengan lidah konsumen yang sensitif terhadap rasa pedas. Tradisi ini secara tidak langsung juga mengadaptasi pola-pola Barat seperti standar hygiene, standarisasi resep, pengolahan dengan mempergunakan peralatan moderen dan sebagainya.

Sejalan dengan hal tersebut, saat sebuah destinasi akan menjadikan kulinernya sebagai bagian dari atraksi pariwisata, maka akan ada beberapa penyesuaian yang harus dilakukan terhadap kuliner Bali tersebut. Disampaikan oleh Cohen dan Avieli (2014), kuliner Bali bagaimanapun juga harus "bertransformasi" jika ingin menjadi konsumsi wisatawan yang populer.

For a local cuisine to become a popular attraction in its own right, it has to be filtered through tourism-oriented culinary establishments; only after they are in some ways, and to some degree, transformed. However, the manner of their transformation can not be simply represented on some unidirectional and unidimensional scale (Cohen dan Avieli 2004:6) 
Transformasi ini menjadikan makanan lokal pada dimensi yang sedikit berbeda dan seringkali disesuaikan oleh selera wisatawan namun tanpa merubah keasliannya. Tidak semua aspek dari kuliner Bali menjadi relevan dengan mempertahankan "keaslian" dari kuliner tersebut. Transformasi dapat dilakukan dengan menggantikan beberapa bahan yang lebih dapat diterima untuk wisatawan dan menggunakan teknologi modern untuk meningkatkan kondisi sanitasi.

Misalnya pada masakan tradisional Thailand tom yam. Tom Yam dikreasikan sehingga tidak terlalu pedas dan asam seperti aslinya sehingga dapat dinikmati oleh masyarakat dunia. Kimchi khas Korea juga dibuat sedemikian rupa sehingga baunya tidak terlalu menyengat. Perubahanperubahan ini dapat dipandang sebagai suatu bentuk budaya yang dinamis tanpa menghilangkan esensi dan cita rasa tradisional dari kuliner tersebut.

Adanya warung makan lokal yang brandingnya diciptakan dan dipopulerkan sendiri oleh wisatawan seperti nasi ayam Kedewatan, Babi Guling Ibu Oka, dan sebagainya merupakan bukti nyata bahwa kuliner Bali dapat bersaing di pasar internasional. Oleh sebab itu pengadopsian seni kuliner ala Barat, sebagai bentuk homogenisasi kebudayaan atau yang sering dikenal dengan sebutan "fast food culture" tidak sepenuhnya terjadi di Ubud. Sebagai destinasi budaya, Ubud justru tetap mampu mempertahankan eksistensi kuliner Bali yang bertaraf internasional

\section{Penutup}

Pengembangan kuliner Bali yang memberi nuansa baru bagi destinasi wisata Ubud merupakan potensi yang harus digali. Pengusaha-pengusaha lokal di Ubud telah membuktikan bahwa kuliner Bali tidak hanya berpotensi bagi peningkatan kesejahteraan namun juga kesempatan untuk mempertahankan kualitas sosial budaya serta keberlanjutan lingkungan jika dikelola secara benar. Oleh sebab itu eksisitensi kuliner lokal harus terus dipertahankan sehingga tetap menjadi ikon pariwisata budaya Ubud.

Keberlanjutan usaha kuliner Bali dapat terus dijaga jika pengusaha lokal secara kreatif terus dapat menumbuhkan kreativitas melalui inovasi. Inovasi produk, promosi serta penciptaan pengalaman wisatawan ini dapat dilakukan dengan tetap mempertahankan cita rasa lokal. Melalui kreativitas kuliner Bali di Ubud akan tetap eksis di tengah derasnya perkembangan pariwisata Ubud.

\section{Ucapan Terima Kasih}

Ucapan terima kasih setulusnya saya sampaikan pada kedua pembimbing saya Prof. I Nyoman Darma Putra M.Litt serta Dr I Nyoman Madiun, M.Ed. Mereka tidak hanya membimbing saya dalam penyelesaian tesis tetapi juga mengajarkan saya bagaimana menjadi seorang dosen dan peneliti kreatif 
dan inovatif. Berkat bimbingan dan dukungan mereka, beberapa tulisan saya telah dipresentasikan dalam konferensi internasional. Support yang terus mengalir membuat saya sering merasa terharu atas ketulusan dan dedikasi meereka. Tulisan ini saya dedikasikan kepada kedua pembimbing saya yang sekaligus merupakan mahaguru dan sahabat peneliti saya.

\section{Daftar Pustaka}

Briggs, Charles L. 1996. The Politics of Discursive Authority in Research on The 'Invention of Tradition. Cultural Anthropology 11 (4) hlm. 435-469.

Cohen, E., dan Avieli, N. 2004. Food in Tourism: Attraction and Ompediment. Annals of Tourism Research, Vol 31(4) hlm. 597-617.

Chang, R. C. Y., Kivela, J., \& Mak, A. H. N. 2010. Food preferences of Chinese tourists. Annals of Tourism Research, 37(4), hlm. 989-1011.

Fox, R. 2007. Reinventing The Gastronomic Identity of Croatian Tourist Destinations. International Journal of Hospitality Management Vol 26 hlm 546-559.

Hall, M dan Mitchell, R. 2002. The Changing Nature of the Relationship Between Cuisine and Tourism in Australia and New Zealand: from Fusion Cuisine to Food Networks. Dalam A. M. Hjalager dan G. Richards (Eds.) Tourism And Gastronomy. Hlm 187-206. London: Routledge.

Hall, C.M. dan Sharples, L. 2003. The Consumption of Experiences or The Experience of Consumption? An Introduction to The Tourism of Taste. Dalam C.M. Hall, L. Sharples, R. Mitchell, N. Macionis dan B. Cambourne (Eds.) Food Tourism Around The World: Development, Management and Markets, ButterworthHeinemann: Oxford.

Harrington, R. J. 2005. Defining Gastronomic Identity: The Impact of Environment and Culture On Prevailing Components, Texture and Flavors In Wine and Food. Journal of Culinary Science and Technology Vol 4(3) hlm 129-152.

Hawkins, D.I., dan Mothersbaugh, D.L. 2010. Consumer Behavior: Building Marketing Strategy.11th edition. McGraw-Hill.

Hjalager dan G. Richards. 2002. Tourism and Gastronomy. London: Routledge.

Hobsbawn, E. and Ranger, T. 1983. The Invention of Tradition. Cambridge: Cambridge University Press.

Kivela, J. dan Crotts, J. 2006. Tourism and Gastronomy: Gastronomy's Influence on How Tourists Experience A Destination. Journal of Hospitality and Tourism Research, Vol. 30(3) hlm. 354-377.

Kapoor C., and Solomon, N. 2011. Understanding And Managing Generational Differences In The Workplace. Worldwide Hospitality and Tourism Themes, Vol. 3 (4) hlm. 308 - 318

Long, L.M. 2010. Culinary Tourism and The Emergence pf Appalachian Cuisine: Exploring the "foodscape" of Asheville, NC. North Carolina Folklore Journal, 57(1) hlm 4-19.

Okumus, B., Okumus, F. dan McKercher, B. 2007. Incorporating local and 
international cuisines in the marketing of tourism destinations: The cases of Hong Kong and Turkey. Tourism Management, Vol. 28 (1), hlm 253- 261.

Nummedal, M. dan Hall, C.M. 2006. Local Food in Tourism: An Investigation Of The

New Zealand South Island's Bed And Breakfast Sector's Use and Perception of Local Food. Tourism Review International, Vol. 9(4) hlm 365-378.

Putra, I Nyoman Darma. 2014. Empat Srikandi Kuliner Bali: Peran Perempuan

Dalam Pembangunan Pariwisata Berkelanjutan. Jurnal Master Pariwisata JUMPA Vol 1(1) hlm. 65-94.

Richards, G. 2002. Gastronomy: An Essential Ingredient in Tourism Production and Consumption? Dalam A. M. Hjalager dan G. Richards (Ed.), Tourism and Gastronomy hlm. 3-20. London: Routledge.

Ritzer, G. 1995. The McDonaldization of Society. London: Sage.

Sims, R. 2009. Food, Place and Authenticity: Local Food and The Sustainable Tourism Experience. Journal of Sustainable Tourism, Vol. 17 (3) hlm. 321-336. Scharpato, Rebecca 2002. Destination Branding: A Snapshot UW-L Journal of Undergraduate Research XVI (2013). Hlm 1-10

Solomon, Michael R. 2009, Consumer Behaviour: Buying, Having and Being, 8th edition, Pearson International Edition.

Symons, M. 1993. The Shared Table: Ideas for Australian Cuisine. Canberra: AGPS Telfer, D.J. dan Wall, G. 200o. Strengthening backward economic linkages: local food purchasing by three Indonesian hotels. Tourism Geographies Vol.2(4) hlm. 421-447Tomlinson, J. 1991. Cultural Imperialism: A Critical Introduction. Baltimore, MD: Johns Hopkins. University Press.

Torres, R. 2002. Toward a Better Understanding of Tourism and Agriculture Linkages in The Yucatan: Tourist Food Consumption and Preferences. Journal of Tourism Geographies 4(3) hlm. 282-306.

Yurtseven, H.R. dan Kaya, Ozan. 2011. "Local Food in Local Menus: The Case of Gokceada”. Tourismos. Volume 6. Number 2. (2011). H: 263-275.

\section{Profil Penulis}

Putu Diah Sastri Pitanatri adalah dosen Jurusan Hospitaliti Sekolah Tinggi Pariwisata Nusa Dua Bali (STPNB). Selain aktif mengajar, Diah sangat senang menulis. Saat ini sudah ada dua buku yang diterbitkan secara internal bersama rekan pengajar di STPNB, yaitu Pengantar Pemasaran (2014) dan Pemasaran Hospitaliti (2015). Beberapa tulisannya juga sudah diterbitkan pada prosiding internasional dan jurnal nasional. Selain kuliner Bali, passion menulisnya ada pada cakupan heritage, cultural tourism, local entrepreneurship dan marketing. Harapan kedepannya adalah bisa menulis buku yang terbit secara nasional serta publikasi di jurnal internasional. 